\title{
Sequence of the fourth and fifth Photosystem II Type I chlorophyll $a / b$-binding protein genes of Arabidopsis thaliana and evidence for the presence of a full complement of the extended $\mathrm{CAB}$ gene family
}

\author{
J. Mitchell McGrath, ${ }^{1}$ William B. Terzaghi, ${ }^{2}$ Padma Sridhar, ${ }^{2,3}$ Anthony R. Cashmore ${ }^{2}$ and \\ Eran Pichersky ${ }^{1}$. \\ ${ }^{1}$ Biology Department, University of Michigan, Ann Arbor, MI 48109, USA $;{ }^{2}$ Department of Biology, \\ Leidy Laboratory of Biology, University of Pennsylvania, Philadelphia, PA 19104, USA ${ }^{3}$ present address: \\ Department of Microbiology, Osmania University, Hyderabad 500007, India (* author for correspondence)
}

Received 25 October 1991; accepted in revised form 24 February 1992

Key words: gene duplication, photosynthesis, RFLP, Southern blots

\begin{abstract}
A second locus $(L h b 1 B)$ encoding Photosystem II Type I chlorophyll $a / b$-binding (CAB) polypeptides was identified in Arabidopsis thaliana. This locus carries two genes in an inverted orientation. The predicted sequences of the polypeptides encoded by these two genes show substantial divergence in their amino termini relative to each other and to the proteins encoded by the three $L h b l \mathrm{CAB}$ genes previously characterized [10], but little divergence within the predicted primary structure of the mature protein. DNA probes derived from seven additional types of tomato CAB genes, encoding chlorophyll $a / b$-binding polypeptides of several antenna systems of the photosynthetic apparatus, were tested against A. thaliana. Each of these hybridized in Southern blots to unique DNA fragment(s), demonstrating the existence of each of these different types of $\mathrm{CAB}$ genes in the genome of $A$. thaliana. The number of genes encoding each CAB type in $A$. thaliana was estimated to be similar to that of tomato.
\end{abstract}

\section{Introduction}

Nuclear-encoded chlorophyll $a / b$-binding $(\mathrm{CAB})$ polypeptides are a distinct class of structurally and evolutionarily related pigment-binding proteins found in chloroplast thylakoid membranes. These proteins are localized in antenna complexes such as the light-harvesting complex I (LHCI) associated with Photosystem I (PSI), and LHCII,
CP24, and CP29 antenna systems associated with PSII. Chlorophyll molecules bound to CAB proteins in these antenna complexes are the primary acceptors of light energy. The LHCI, LHCII, CP24 and CP29 antenna complexes have been identified in many plant species, including Arabidopsis thaliana [1]. To date, we have isolated and characterized tomato genes encoding four different types of $\mathrm{CAB}$ polypeptides of $\mathrm{LHCI}$,

The nucleotide sequence data reported will appear in the EMBL, GenBank and DDBJ Nucleotide Sequence Databases under the accession numbers X64459 (LhblBl) and X64460 (Lhb1B2). 
three different types of LHCII CAB polypeptides, one type of $\mathrm{CP} 29 \mathrm{CAB}$ polypeptide, and one type of CP24 CAB polypeptide [4, 22]. In A. thaliana, three tandemly linked genes encoding PS II Type I proteins have been isolated [10], and recently the isolation of a PSI Type IV gene was reported [26]. We report here (1) the sequence of two additional PSII Type I genes from $A$. thatiana, and (2) that homologous sequences to most, if not all, types of $\mathrm{CAB}$ genes identified to date exist in A. thaliana.

\section{Materials and methods}

Plant material, probes, and genomic Southern blots

Three ecotypes of $A$. thaliana ('Columbia', 'Landsberg', and 'Niederzanz') were used in this study. DNA from each race, extracted as described [19], was digested ( $2 \mu \mathrm{g}$ per sample) with restriction enzymes, electrophoresed in a $0.8 \%$ agarose gel and alkaline-blotted to Hybond membrane (Amersham) according to the manufacturer's recommendations. Random-primed ${ }^{32} \mathrm{P}$-labelled probes were prepared from the coding regions of the tomato genes encoding the different types of $\mathrm{CAB}$ proteins, and also from $A$. thaliana sequences flanking $L h b l$ CAB genes (Table 1). Hybridization was carried out at $65^{\circ} \mathrm{C}$ in a solution containing $5 \times \mathrm{SSPE}, 5 \times$ Den- hardt's solution, $0.5 \% \mathrm{SDS}$, and $0.1 \mathrm{mg} / \mathrm{ml}$ fish sperm DNA [18]. With the single exception of the $L h b 1$ and $L h b 2$ genes, different types of tomato $\mathrm{CAB}$ genes are $>50 \%$ divergent from each other, and do not cross-hybridize under the conditions utilized (i.e. final wash at $65^{\circ} \mathrm{C}, 1 \times \mathrm{SSC}, 0.5 \%$ SDS). Blots probed with the tomato $L h b 2$ gene were washed at higher stringency $\left(65^{\circ} \mathrm{C}, 0.2 \times\right.$ SSC, $0.1 \%$ SDS).

\section{Isolation and sequence analysis of recombinant bac- teriophage}

Recombinant bacteriophage were isolated from a lambda DASH library of $A$. thaliana (race Columbia) genomic DNA (courtesy of Dr Nigel Crawford). Library screening followed standard techniques [18]. Nucleotide sequences were determined for both strands, and sequence data were analyzed using the MacVector program and a MacIntosh II computer.

\section{Linkage analysis}

A total of $57 \mathrm{~F}_{2}$ plants derived from a single $F_{1}$ individual of the Landsberg $\times$ Niederzanz cross were allowed to self. $F_{3}$ seeds from each of the individual $F_{2}$ plants were germinated and pooled for DNA extraction. The MAPMAKER com-

Table 1. Tomato and $A$. thaliana $\mathrm{CAB}$ gene probes utilized in this study. CAB gene nomenclature adopted from Jansson et al. [8].

\begin{tabular}{|c|c|c|c|c|}
\hline Gene & Synonym & Probe & Fragment used $(\mathrm{kb})$ & Ref. \\
\hline Lhal & PS I Type I & $c a b 6 A^{\mathrm{a}}$ & $0.28(N c o \mathbf{I}+E c o$ RI $)+0.45 N c o \mathbf{I}$ & {$[6]$} \\
\hline Lha2 & PS I Type II & $c a b 7^{a}$ & 0.9 Hind III + Eco RI & [14] \\
\hline Lha3 & PS I Type III & $c a b 8^{\mathrm{a}}$ & 0.55 Hind III & {$[15]$} \\
\hline Lha4 & PS I Type IV & $c a b 11^{\mathrm{a}}$ & $0.7 P_{s t} \mathrm{I}+H u n d \mathrm{III}$ & [21] \\
\hline $\operatorname{Lhbl}$ & PS I Type I & $c a b 3 C^{\mathrm{a}}$ & $1.3 X b a \mathrm{I}+$ Hind III & {$[12]$} \\
\hline Lhb1A & & $\mathrm{p} 1655^{\mathrm{b}}$ & $0.8 E c o \mathrm{RI}+X b a \mathrm{I}$ & This paper \\
\hline$L h b I B$ & & $\mathrm{p} 3^{\prime} \mathrm{CD}^{\mathrm{b}}$ & $3.1 X b a \mathrm{I}+S a l \mathrm{I}$ & This paper \\
\hline$L h b 2$ & PS II Type II & $c a b 5$ & $(\mathrm{p} 3-48) 0.5 P_{s t} \mathrm{I}$ & {$[13]$} \\
\hline$L h b 5$ & CP29 Type $I^{a}$ & $c a b 9^{\mathrm{a}}$ & $0.8 S s t \mathrm{I}+B a l \mathrm{I}$ & {$[17]$} \\
\hline Lhb6 & $\mathrm{CP} 24$ & $c a b 10 B^{\mathrm{a}}$ & 0.7 Pst I + Hind III & [20] \\
\hline
\end{tabular}

${ }^{a}$ Tomato gene.

${ }^{\mathrm{b}}$ Locus-specific probe from $A$. thaliana isolated for this study. 
puter algorithm was used for linkage analyses [9].

\section{Results and discussion}

Identification and characterization of two genes residing at a second Lhb1 locus

Leutwiler et al. [10] characterized three $L h b 1$ genes residing on an $11 \mathrm{~kb}$ fragment of $A$. thaliana genomic DNA. Following guidelines for a standard $\mathrm{CAB}$ gene nomenclature system $[8$, see Table 1 for a cross-reference between $\mathrm{CAB}$ gene nomenclatures], we have re-designated the genes characterized by Leutwiler et al. [10] as Lhb1A1 ( = AB140 [10]), Lhb1A2 (= AB 165) and Lhb1A3 $(=\mathrm{AB} 180)$. Here we report the isolation and characterization of two additional, tandemly linked A. thaliana Lhbl genes. Because our evidence indicates these two genes reside at a separate locus from the three previously characterized $L h b 1$ genes (see below), we have designated them as $L h b 1 B 1$ and LhblB2.

Four genomic $L h b 1 B$ clones were recovered by plaque hybridization with a probe derived from the coding region of $A$. thaliana LhblA1 [10]. A $6.0 \mathrm{~kb}$ Pst I fragment common to all four was found to contain two tandemly linked genes (in inverse orientation) separated by $1.3 \mathrm{~kb}$ of noncoding DNA (Fig. 1A). No other CAB genes were found within $10 \mathrm{~kb}$ spanning either side of the Lhb1 genes carried by these four clones (Fig. 1 and data not shown). Sequence comparison of the two $L h b l B$ CAB genes presented here, $L h b 1 B 1$ and $L h b 1 B 2$, and the three LhblA CAB genes previously characterized [10] indicates an overall similarity $>85 \%$ at the nucleotide sequence; sequence divergence between $L h b 1 B 1$ and $L h b 1 B 2$ lies largely within the regions encoding the transit peptide and amino terminus of the mature protein (Figs. 1B, 1C). In contrast, nucleotide sequence differences between $L h b 1 B$ and $L h b l A$ genes are more evenly spread throughout the coding regions. The deduced amino acid sequences of all five mature $L h b 1$ polypeptides are nearly identical to one another $(>95 \%)$, but there are a few locus-specific differences (Fig. 1C).

\section{Evidence for two unlinked Lhb1 CAB loci}

The Southern blot patterns we obtained with the tomato $L h b 1$ gene probe displayed multiple fragments with all restriction enzymes used (Figs 24). They were also more complex than patterns previously observed [10]. Previously, restriction maps of the cloned $L h b 1 A$ genes and Southern blots of $A$. thaliana genomic DNA (probed with one of the $A$. thaliana cloned genes) showed that the three $L h b 1 A$ genes reside on $1.65 \mathrm{~kb}$ ( $L h b 1 A 2)$, $1.8 \mathrm{~kb}$ (Lhb1A3), and $6.0 \mathrm{~kb}$ (Lhb1A1) Eco RI fragments, and $1.4 \mathrm{~kb}$ (Lhb1A1), $3.8 \mathrm{~kb}$ (Lhb1A2) and $5.5 \mathrm{~kb}(L h b 1 A 3) H i n d$ III fragments [10]. We observed these same fragments on our Southern blots as well (Fig. 2, marked with filled squares). A previously observed but uncloned $2.0 \mathrm{~kb}$ Hind III fragment [10] is indicated in Fig. 2 as an open square. It carries the $L h b 1 B 1$ gene (Fig. 1A). A second previously uncloned Hind III fragment of $1.4 \mathrm{~kb}$, carrying the Lhb1B2 gene, was originally missed [10] because it overlaps with the 1.4 $\mathrm{kb} H$ ind III fragment of the $L h b l A$ gene (Figs. 1A, 2). However, our Southern blots displayed additional fragments (Fig. 2) as compared with the Southern blots in [10]. It seems likely that differences between our results and the previous results are due both to our utilization of lowerstringency hybridization conditions and to our recovery of high-molecular-weight DNA. The latter supposition may explain why the previous study did not detect the additional strongly hybridizing, high-molecular-weight $(>25 \mathrm{~kb})$ Eco RI fragment detected in our blots (Fig. 2) (E. Meyerowitz, personal communication). In addition, an Eco RI fragment $>25 \mathrm{~kb}$ would not be present in a lambda phage-based genomic library of Eco RI-digested $A$. thaliana DNA [10], which explains why the $L h b 1 B$ genes were not recovered in the previous study.

Identification of two unlinked $L h b l$ loci was aided by the isolation of cloned DNA adjacent to both $L h b 1$ gene clusters. Locus-specific probes derived from a non-coding region of $L h b 1 B$ identified $X b a$ I fragments of ca. $15 \mathrm{~kb}$ from 'Niederzanz' (and 'Columbia') and ca. $17 \mathrm{~kb}$ from 'Landsberg' as LhblB (Fig. 2). The LhblB locus- 

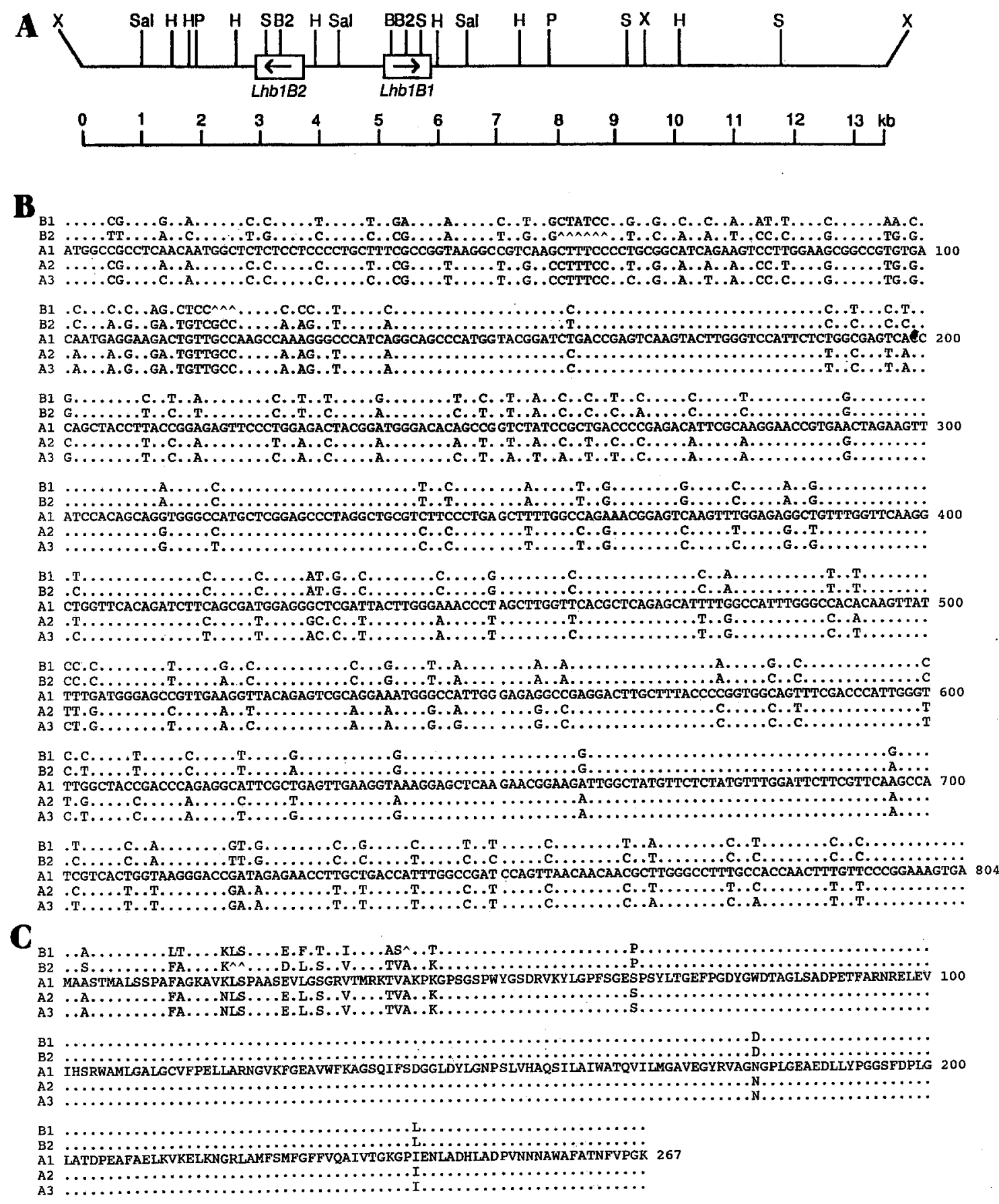

Fig. 1. A. Restriction map of LhblB CAB genes (B, Bam HI; B2, Bgl II; H; Hind III; P, Pst I; S, Sac I; Sal, Sal I; X, Xba I). $B$. Nucleotide sequence comparison of $A$. thaliana Lhb1 CAB genes aligned and numbered relative to Lhb1A1 [data from 10]. Note that both $L h b 1 B$ CAB genes have suffered deletions (indicated by ${ }^{\wedge}$ ) within the first $150 \mathrm{bp}$ compared with $L h b 1 A$. C. Predicted polypeptide sequence of $L h b 1 \mathrm{CAB}$ genes aligned relative to $L h b 1 A 1$ [data from 10].

specific probes also hybridized strongly with a single Eco RI fragment $>25 \mathrm{~kb}$ (Fig. 2). Similarly, a gene-specific probe derived from a non- coding region of $L h b 1 A$ (the promoter of $L h b 1 A 2$ ) identified the polymorphic $X b a \mathrm{I}$ fragments $>20 \mathrm{~kb}$ as the LhblA locus and did not hybrid- 

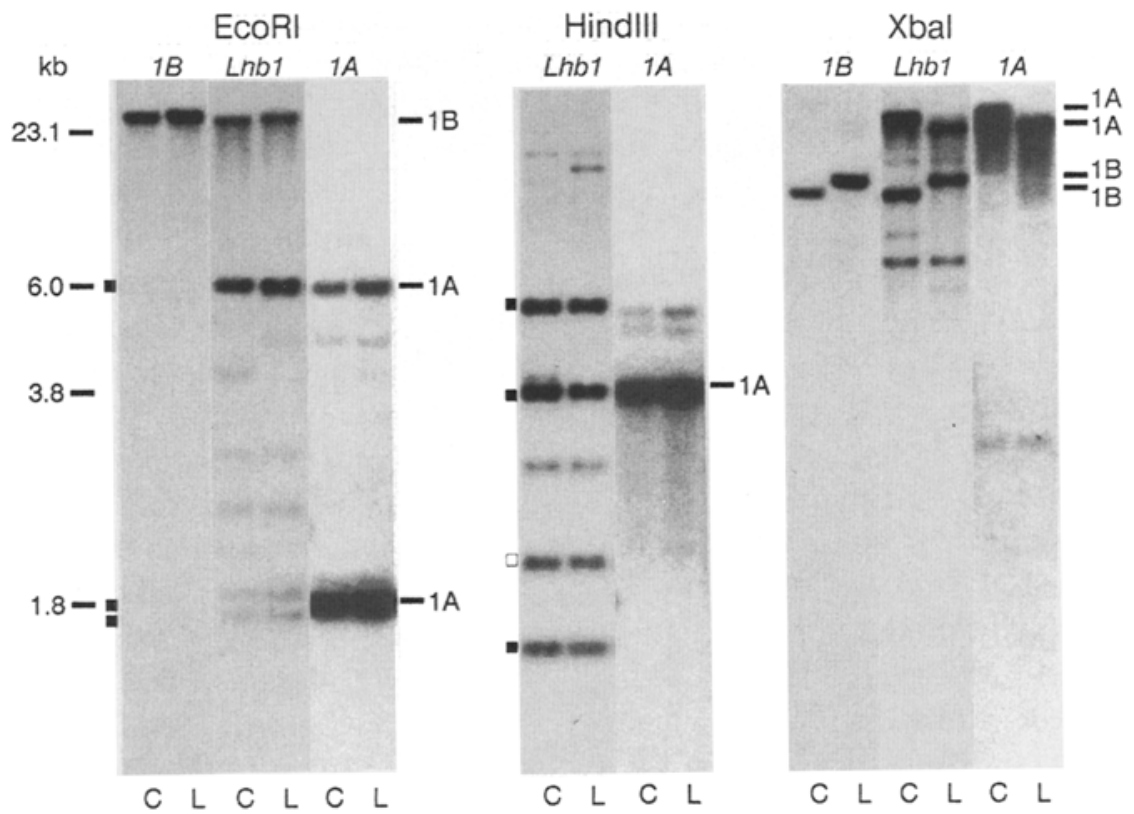

Fig. 2. Comparisons of Southern blots of 'Columbia' (C) and 'Landsberg' (L) DNA digested with three restriction enzymes and probed with tomato $L h b 1$ gene probe (lane $L h b 1$ ), A. thaliana LhblA locus-specific probe (lanes 1A) and A. thaliana LhblB locus-specific probe (lanes $1 B$ ). Alphanumerics at the right of each panel indicate the locus designation of each polymorphic fragment identified in the segregation analysis (i.e., $1 \mathrm{~A}=\operatorname{Lhb1A} ; 1 \mathrm{~B}=L h b 1 B$ ). Boxes indicate the position of fragments observed in the Southern blots of Leutwiler et al. [10] (see text for details).

ize with the smaller $X b a I$ fragments or $>25 \mathrm{~kb}$ Eco RI fragment (Fig. 2). Independent segregation of these polymorphisms in Landsberg $x$ Niederzanz $\mathrm{F}_{3}$ families indicated that the two loci, $L h b 1 A$ and $L h b 1 B$, are unlinked (Fig. 3).

These data indicate that $A$. thaliana has at least five $L h b 1$ genes. Tomato has eight such genes [16], and all other species examined, with perhaps one exception, possess five or more $L h b 1$ genes (for examples see $[2,3]$ ). The exception was from cucumber in which a Southern blot of
Hind III-digested DNA showing six bands was interpreted to indicate that the cucumber genome possesses only two Lhbl genes [5]. However, this estimate was based on an untested assumption that each cucumber $L h b 1$ gene contained an internal Hind III site which the probe spanned (although this should still give an estimate of three genes, rather than two). Also not taken into consideration was the possibility that genes were tandemly linked, a common arrangement for $L h b l$ genes $[2,10,12]$, and thus several genes may

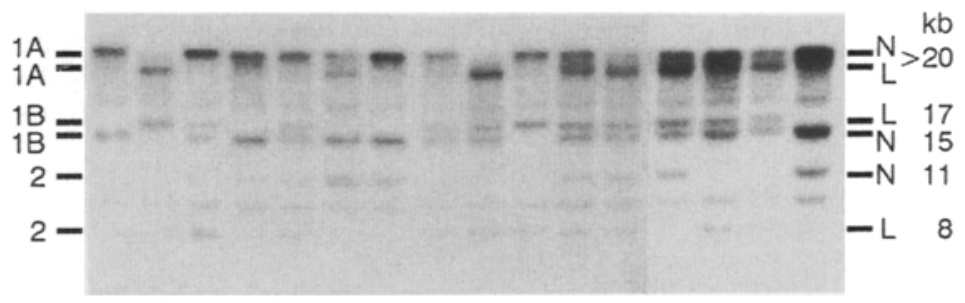

Fig. 3. $\mathrm{F}_{3}$ segregation at three loci. The $\mathrm{DNA}$ of pooled $\mathrm{F}_{3}$ plants from individual $\mathrm{F}_{2}$ plants was digested with $X b a \mathrm{I}$, and the probe was a tomato $L h b 1 \mathrm{CAB}$ gene. Fragments labelled $1 \mathrm{~A}$ and $1 \mathrm{~B}$ are alleles of the $L h b 1 A$ and $L h b 1 B$ loci, respectively. Fragments labelled 2 are alleles of $L h b 2$ (see text). $\mathrm{N}=$ 'Niederzanz' allele; $\mathrm{L}=$ 'Landsberg' allele. 
wholly or partially reside on a single fragment. Hence, re-evaluation of the cucumber data suggests that the number of $L h b 1$ genes in cucumber is likely to be greater than two, and possibly as many as five.

\section{Evidence for an Lhb2 locus in A. thaliana}

Genes encoding Photosystem II Type II CAB proteins (designated as $L h b 2$ genes) are $70 \%$ identical to $L h b 1$ genes [13]. Thus, some of the fragments we observed in our blots probed with the $L h b 1$ probe are likely to carry $L h b 2$ genes. Consistent with this hypothesis, Southern blots probed with the tomato $L h b 2$ gene displayed a set of hybridizing fragments which largely overlapped the set of fragments hybridizing to the $L h b 1$ probe. However, the two probe types hybridized with different efficiency to individual fragments, as seen in side-by-side comparisons of autoradiographs probed with the $L h b 1$ and $L h b 2$ probes and examined for relative differences in intensities of all fragments within the same DNA sample (compare Figs. 4a, b).

All fragments which showed preferential hybridization to the $L h b 2$ probe and which were polymorphic between accessions were tested for segregation. With each of the four restriction enzymes tested, these fragments mapped to the same genetic locus, designated $L h b 2$, and this locus segregated independently from $L h b I A$ and $L h b 1 B$ (Fig. 3 and data not shown). For example, $X b a$ I fragments of 8 and $11 \mathrm{~kb}$ hybridized more intensely with the $L h b 2$ probe than with the $L h b 1$ probe (compare Figs. 4a, 4b) and they segregated independently from the $L h b 1$ fragments (Fig. 3).

As in the case of $L h b 1 A$ and $L h b 1 B$ loci, frag-

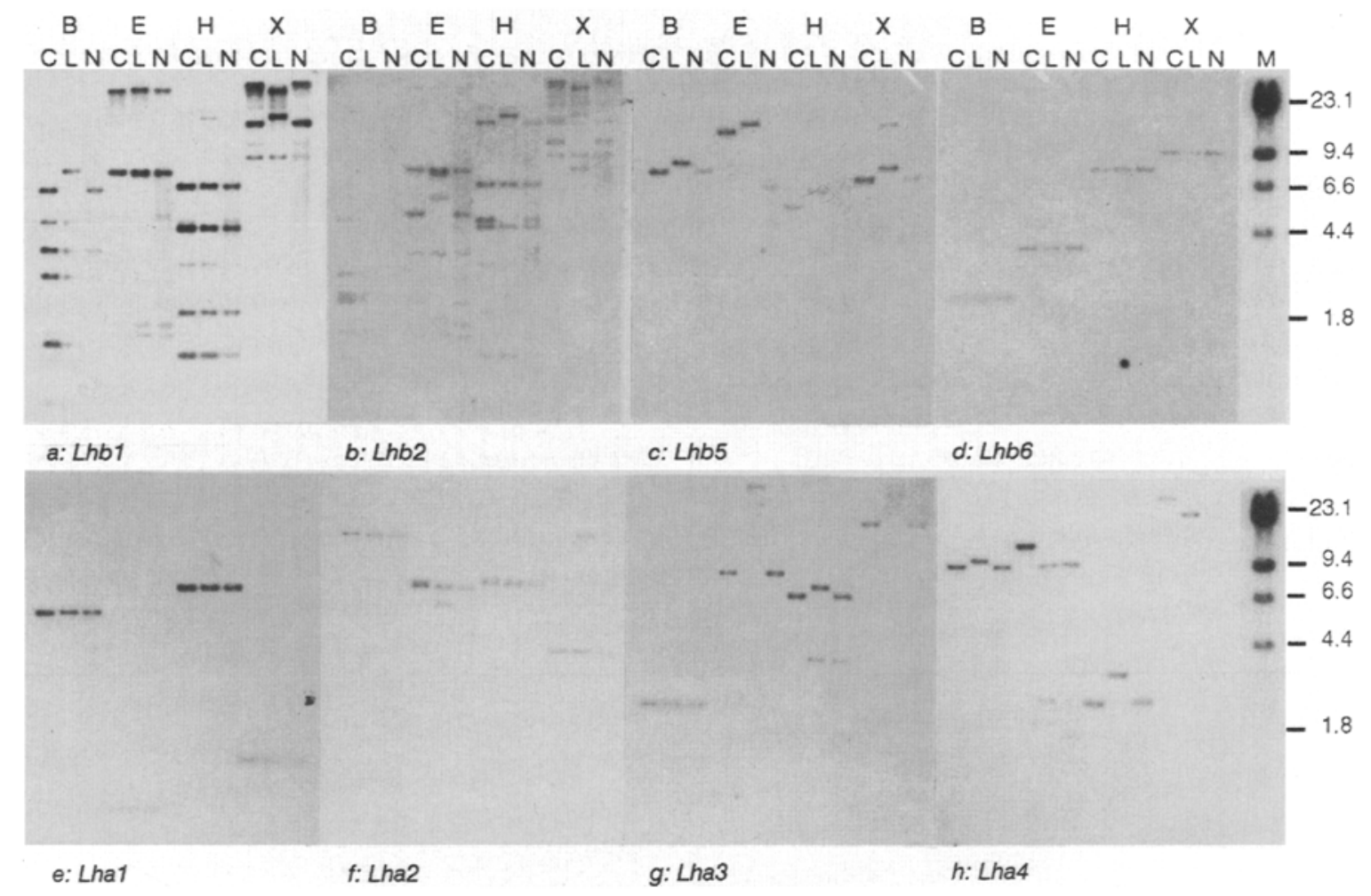

Fig. 4. Southern blots of $A$. thaliana $\mathrm{DNA}$ from three ecotypes $(\mathrm{C}=$ 'Columbia'; $\mathrm{L}=$ 'Landsberg'; $\mathrm{N}=$ 'Niederzanz'; ) probed with eight different tomato $\mathrm{CAB}$ genes types. In each panel, the three lanes on the left are DNA digested with $B g l$ II (B), next three lanes are DNA cut with Eco RI (E), the next three lanes with Hind III (H), and the last three lanes on the right with $X b a$ I (X). (See Table 1 for the source and size of the probes). 
ment(s) identifying the $L h b 2$ locus were also large enough to contain multiple copies of this gene, and further study is required to determine the exact number of the $L h b 2$ genes in the $A$. thaliana genome. Since not all hybridizing fragments in all blots with the $L h b 1$ and $L h b 2$ probes could be mapped, estimates presented for the number of loci and the number of genes of these two $\mathrm{CAB}$ types (Table 2) are minimal estimates. In addition, other faint bands, which could not be mapped for lack of polymorphism, were present in these two blots, and may indicate the presence of a third PSII CAB gene type ( $L h b 3$ ) recently identified in tomato [22]. Probing A. thatiana DNA with the tomato $L h b 3$ gene gave a weak hybridization signal which was difficult to interpret (data not shown), but the existence of the $L h b 3$ gene product in $A$. thaliana has recently been reported [11].

Evidence for other members of the extended $C A B$ gene family in A. thaliana

We prepared eight duplicate Southern blots of DNA from three different $A$. thatiana ecotypes each digested with four different restriction enzymes. In addition to $L h b 1$ and $L h b 2$ probes, each of the other six blots was probed with one of six other tomato $\mathrm{CAB}$ gene types (see Table 1). Results indicate that each probe hybridized to

Table 2. Comparison between the number of genes from each different $\mathrm{CAB}$ type in tomato with the estimate for the minimum number of corresponding genes in $A$. thaliana.

\begin{tabular}{|c|c|c|c|c|}
\hline & \multicolumn{2}{|c|}{ A. thatiana } & \multicolumn{2}{|l|}{ Tomato } \\
\hline & $\begin{array}{l}\text { Number } \\
\text { of loci }\end{array}$ & $\begin{array}{l}\text { Number } \\
\text { of genes }\end{array}$ & $\begin{array}{l}\text { Number } \\
\text { of loci }\end{array}$ & $\begin{array}{l}\text { Number } \\
\text { of genes }\end{array}$ \\
\hline Lhal & 1 & 1 & 1 & 2 \\
\hline Lha2 & $\geq 1$ & $\geq 1$ & 1 & 1 \\
\hline Lha3 & 1 & 1 & 1 & 1 \\
\hline Lha4 & 1 & 1 & 2 & 2 \\
\hline$L h b 1$ & $\geq 2$ & $\geq 5$ & 3 & 8 \\
\hline$L h b 2$ & $\geq 1$ & $\geq 1$ & 2 & 2 \\
\hline Lhb5 & 1 & $\geq 1$ & 1 & 1 \\
\hline Lhb6 & 1 & 1 & 1 & 2 \\
\hline
\end{tabular}

one or a few fragments (Fig. 4). The fragments to which these probes hybridized were unique and were not recognized by other tomato $\mathrm{CAB}$ gene probes.

The tomato genes encoding Lhal and Lhb6 each recognized a single fragment with all enzymes tested (Fig. 4e and 4d, respectively). The minimum fragment size observed with the Lhal probe was ca. $0.75 \mathrm{~kb}$, and the minimum size fragment identified by the $L h b 6$ probe was ca. 2.5 $\mathrm{kb}$. With the tomato probes for Lha3, Lha4, and Lhb5 single fragments were commonly seen (Fig. 4g, h, c). The Lha3 probe showed a minimum fragment size of ca. $3.0 \mathrm{~kb}$ with the enzyme $B g l$ II. Likewise, the smallest fragment seen with the $L$ ha 4 probe was ca. $2.5 \mathrm{~kb}$. Fragment sizes of $<3 \mathrm{~kb}$ were considered to be large enough to code for only a single gene (i.e. coding region, introns and promoter region). The minimum fragment size observed with the tomato $L h b 5$ probe was ca. $6.0 \mathrm{~kb}$, which is sufficient to contain a tandem duplication in this region. Therefore, further experiments need to be done to determine if A. thaliana has one or two genes for the $L h b 5$ protein. With the Lha 2 probe, two or three fragments were seen in most enzyme digests (Fig. 4f). It seems possible that $A$. thaliana has more than one gene encoding the Lha2 protein; tomato has a single gene of this kind [16], while petunia has several [23].

We conclude from the Southern blot data that the $A$. thaliana genome contains genes homologous to all eight different types of tomato $\mathrm{CAB}$ genes used in this study. These data also demonstrate that, although the different $\mathrm{CAB}$ genes are structurally and evolutionarily related, substantial divergence has occurred between CAB gene types such that probes derived from different $C A B$ genes within the same organism do not usually cross-hybridize. Thus an estimate of the minimum number of $\mathrm{CAB}$ genes within a species cannot be obtained from Southern blots unless an entire set of $\mathrm{CAB}$ genes are used as probes. Our data also demonstrate that $\mathrm{CAB}$ genes of a specific type are more similar to genes encoding the same type in other species than are $\mathrm{CAB}$ gene types within species, and that the number of $\mathrm{CAB}$ 
genes in $A$. thaliana is roughly equivalent to the numbers seen in tomato (Table 2).

Chlorophyll $a / b$-binding polypeptides were first discovered in the light-harvesting complex of PSII $[24,25]$. Since then, the discovery of structurally and evolutionarily related $\mathrm{CAB}$ polypeptides in other antenna systems (LHCI, CP29, CP24) has resulted in the characterization of an 'extended' gene family whose members encode these proteins $[4,16]$. The data presented here demonstrate the existence in the $A$. thaliana genome of all the different types of $\mathrm{CAB}$ genes presently known, consistent with the observation that all the different types of antenna complexes are present in the thylakoid membranes of $A$. thaliana chloroplasts [1]. These results also suggest that other plant species will be found to possess all or most of these genes, as has been partly demonstrated in the gymnosperm Scots pine [7].

\section{Acknowledgements}

We thank Dr J. Scheifelbein for providing $A$. thaliana DNA, R. Wilson for providing $\mathrm{F}_{3}$ seed, Dr N. Crawford for the $A$. thaliana genomic library and Dr R. Donald for the Lhb1A locusspecific probes. This work was supported by grants from USDA (CSRS 90-37262-5448) and NSF (DMB-8819210) to E.P. and DOE (DEFG02-87ER13680) to A.R.C. W.B.T. was supported by NSF postdoctoral fellowship DCB8807578 .

\section{References}

1. Allen KD, Falbel TG, Shaw AL, Bennet A, Staehelin LA: Resolution of up to eighteen chlorophyll-protein complexes from vascular plant thylakoids using a new green gel system. In: Baltscheffsky $M$ (ed) Current Research in Photosynthesis, Vol. II, pp. 269-272. Kluwer Academic Publishers, Dordrecht, The Netherlands (1990).

2. Castresana C, Stanelone R, Malik VS, Cashmore AR: Molecular characterization of two clusters of genes encoding Type I CAB polypeptides of PSII in Nicotiana plumbaginifolia. Plant Mol Biol 10: 117-126 (1987).

3. Dunsmuir P: The petunia chlorophyll $a / b$-binding protein genes: a comparison of $\mathrm{CAB}$ genes of different gene families. Nucl Acids Res 13: 2503-2518 (1985).
4. Green BR, Pichersky E, Kloppstech K: Chlorophyll $a / b$ binding proteins: an extended family. Trends Biochem Sci 16: 181-186 (1991).

5. Greenland AJ, Thomas MV, Walden RM: Expression of two nuclear genes encoding chloroplast proteins during early development of cucumber seedlings. Planta 170: 99-110 (1987).

6. Hoffman NE, Pichersky E, Malik VS, Castresana C, Ko $\mathrm{K}$, Darr SC, Cashmore AR: The nucleotide sequence of a tomato cDNA clone encoding a photosystem I protein with homology to photosystem II chlorophyll $a / b$-binding polypeptides. Proc Natl Acad Sci USA 84: 8844-8848 (1987).

7. Jansson S, Gustafsson P: Evolutionary conservation of the chlorophyll $a / b$-binding proteins: cDNAs encoding Type I, II and III LHC I polypeptides from the gymnosperm Scots pine. Mol Gen Genet 229: 67-76 (1991).

8. Jansson S, Pichersky E, Bassi R, Green BR, Ikeuchi M, Melis A, Simpson DJ, Spangfort M, Staehelin LA: A nomenclature for the genes encoding the chlorophyll a/ $b$-binding proteins of higher plants. Plant Mol Biol Rep, in press.

9. Lander EC, Green P, Abrahamson J, Barlow A, Daly MJ, Lincoln SE, Newburg L: MAPMAKER: An interactive computer package for constructing primary genetic linkage maps of experimental and natural populations. Genomics 1: 174-181 (1987).

10. Leutwiler LS, Meyerowitz EM, Tobin EM: Structure and expression of three light-harvesting chlorophyll $a / b$ binding protein genes in Arabidopsis thaliana. Nucl Acids Res 14: 4051-4064 (1986).

11. Morishige DT, Thornber JP: Correlation of apoproteins with the genes of the major chlorophyll $a / b$-binding protein of photosystem II in Arabidopsis thaliana. FEBS Lett 293: 183-187 (1991).

12. Pichersky E, Bernatzky R, Tanksley SD, Breidenbach W, Kausch A, Cashmore AR: Isolation, molecular characterization, and genetic mapping of two clusters of genes encoding chlorophyll $a / b$-binding proteins in Lycopersicon esculentum (tomato). Gene 40: 247-258 (1985).

13. Pichersky E, Hoffman NE, Malik VS, Bernatzky R, Tanksley SD, Szabo L, Cashmore AR: The tomato Cab-4 and $C a b-5$ genes encode a second type of CAB polypeptides localized in Photosystem II. Plant Mol Biol 9: 109120 (1987).

14. Pichersky E, Tanksley SD, Piechulla B, Stayton MM, Dunsmuir P: Nucleotide sequence and chromosomal location of $\mathrm{Cab}-7$, the tomato gene encoding the Type II chlorophyll $a / b$-binding polypeptide of Photosystem I. Plant Mol Biol 11: 69-71 (1988).

15. Pichersky E, Brock TG, Nguyen D, Hoffman NE, Piechulla B, Tanksley SD, Green BR: A new member of the $\mathrm{CAB}$ gene family: structure, expression and chromosomal location of $C a b-8$, the tomato gene encoding the Type III chlorophyll $a / b$-binding polypeptide of photosystem I. Plant Mol Biol 12: 257-270 (1989). 
16. Pichersky E, Green BR: The extended family of chlorophyll $a / b$-binding proteins of PSI and PSII. In: Baltscheffsky M (ed) Current Research in Photosynthesis, Vol III, pp. 553-556. Kluwer Academic Publishers, Dordrecht, The Netherlands (1990).

17. Pichersky E, Subramanian R, White MJ, Reid J, Aebersold R, Green BR: Chlorophyll $a / b$-binding (CAB) polypeptides of $\mathrm{CP} 29$, the internal chlorophyll $a / b$ complex of PSII: characterization of the tomato gene encoding the $26 \mathrm{kDa}$ (Type I) polypeptide, and evidence for a second CP29 polypeptide. Mol Gren Genet 227: 277-284 (1991).

18. Sambrook J, Fritsch EF, Maniatis T: Molecular Cloning: A Laboratory Manual, 2nd ed. Cold Spring Harbor Press, Cold Spring Harbor, NY (1989).

19. Saghai-Maroof MA, Soliman KM, Jorgensen RA, Allard RW: Ribosomal DNA spacer-length polymorphisms in barley: Mendelian inheritance, chromosomal location, and population dynamics. Proc Natl Acad Sci USA 81: 8014-8018 (1984).

20. Schwartz E, Pichersky E: Sequence of two tomato nuclear genes encoding chlorophyll $a / b$-binding proteins of CP24, a PSII antenna component. Plant Mol Biol 15: $157-169$ (1990).
21. Schwartz E, Shen D, Aebersold R, McGrath JM, Pichersky E, Green BR: Nucleotide sequence and chromosomal location of $C a b 11$ and $C a b$ 12, the genes for the fourth polypeptide of the photosystem I light-harvesting antenna (LHCI). FEBS Lett 280: 229-234 (1991).

22. Schwartz E, Stasys R, Aebersold R, McGrath JM, Green BR, Pichersky E: Sequence of a tomato gene encoding a third type of LHCII chlorophyll $a / b$-binding polypeptide. Plant Mol Biol 17: 923-925 (1991).

23. Stayton MM, Brosio P, Dunsmuir P: Characterization of a full-length cDNA clone encoding a polypeptide of the light-harvesting complex associated with photosystem I. Plant Mol Biol 10: 127-137 (1987).

24. Thornber JP, Gregory RPF, Smith CA, Legget-Bailey J: Studies on the nature of the chloroplast lamella. I. Preparation and some properties of two chlorophyll-protein complexes. Biochemistry 6: 391-396 (1967).

25. Ogawa T, Obata F, Shibata K: Two pigment-proteins in spinach chloroplasts. Biochim Biophys Acta 112: 223234 (1966).

26. Zhang H, Hanley S, Goodman HM: Isolation, characterization and chromosomal location of a new $c a b$ gene from Arabidopsis thaliana. Plant Physiol 96: 1387-1388 (1991). 